\title{
Retraction Note to: Increased neuroinflammatory and arachidonic acid cascade markers, and reduced synaptic proteins, in brain of HIV-1 transgenic rats
}

Jagadeesh Sridhara Rao ${ }^{*}$, Hyung-Wook Kim, Matthew Kellom, Dede Greenstein², Mei Chen', Andrew David Kraft ${ }^{3}$, Gaylia Jean Harry ${ }^{3}$, Stanley Isaac Rapoport ${ }^{1}$ and Mireille Basselin ${ }^{1}$

\section{Retraction Note}

This article [1] has been retracted by the editor because author Stanley I Rapoport alerted the editor, and the National Institutes of Health subsequently confirmed, that the data represented by Figs. 1, 4, 5, 6 and 7 were falsified. Stanley I Rapoport, Andrew David Kraft, Gaylia Jean Harry, Matthew Kellom, Hyung-Wook Kim and Dede Greenstein support this retraction. The other authors have not responded to our correspondence with them about the retraction of their article.

\footnotetext{
Author details

${ }^{1}$ Brain Physiology and Metabolism Section, National Institute on Aging, Bethesda, MD 20892, USA. ${ }^{2}$ National Institute of Mental Health, National Institutes of Health, Bethesda, MD 20892, USA. ${ }^{3}$ Laboratory of Toxicology and Pharmacology, National Institute of Environmental Health Sciences, National Institutes of Health, Research Triangle Park, NC 27709, USA.
}

Received: 4 April 2017 Accepted: 25 April 2017

Published online: 09 May 2017

\section{References}

1. Rao JS, Kim HW, Kellom M, Greenstein D, Chen M, Kraft AD, Harry GJ,

Rapoport SI, Basselin M. Increased neuroinflammatory and arachidonic acid cascade markers, and reduced synaptic proteins, in brain of HIV-1 transgenic rats. J Neuroinflammation. 2001;8:101

\footnotetext{
* Correspondence: jrao@mail.nih.gov

The online version of the original article can be found under doi:10.1186/ 1742-2094-8-101.

${ }^{1}$ Brain Physiology and Metabolism Section, National Institute on Aging, Bethesda, MD 20892, USA
} 